\section{Economic Assessment of Methods of Coal and Gas Outburst Prevention in the Extraction of Coalfaces}

\author{
Vlastimil Hudeček, Michal Vaněk, Igor Černý \\ VSB-Technical University of Ostrava, Czech Republic
}

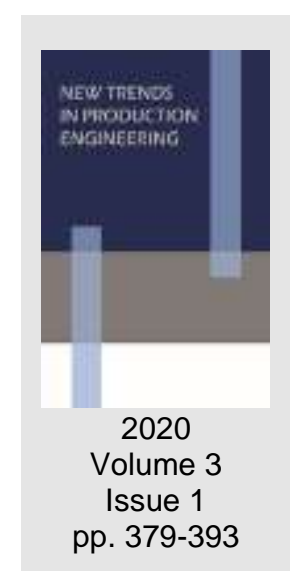

Date of submission to the Editor: 02/2020

Date of acceptance by the Editor: 03/2020

\title{
INTRODUCTION
}

Coal is a fossil fuel mineral that has a variety of uses, including the generation of electricity, metallurgical applications such as steelmaking, cement manufacture, and petroleum fuel production (Budeba \& Joubert, 2014). With the extension of coal mining to depth, coal and gas outburst disasters become more and more serious. In order to ensure the safety, high efficiency and sustainable development of outburst mines, regional outburst prevention has become an important measure for the safe mining of outburst coal seams. At present, regional outburst prevention measures mainly include protective seam mining, predrainage of coal seam gas from surface wells, underground cross-seam and pre-drainage of coal seam gas along seams (Zhang, 2018).

Rock bursts are an extreme behaviour in coal mine strata that can cause fatalities and severe economic losses. Pressure relief drilling is a widely used method in coal mines to release high stress concentrations and effectively reduce the rock mass volumetric elastic potential energy; thus, this method can effectively reduce the occurrence of rock bursts in underground coal mines (Zhang, 2019).

In a number of coal and non-coal basins of the world, the sudden release of gases - blower, and rock and gas outburst occur during mining of deposits with increased gas emission (methane, $\mathrm{CO}_{2}$ ), in addition to the usual continuous release of mine gases. Rock and gas outbursts have been known in world practice of underground mining for more than 150 years Lat et al. (2007), (Franczek, 2006, Hudeček, et. al. 2010, Singh, 2009, Hanes, 2004, Singh, 2008).

The Czech Republic, at the time when it was still part of the Austro-Hungarian Empire, outbursts had been registered since 1894 in the former Ignát Mine (later renamed the Jan Šverma Mine) in the Ostrava-Karvina Coal District (OKR) (Hudeček, 2014, Hudeček \& Urban, 2006).

Over the period from 1894 to 2014, 497 coal and gas outbursts occurred in the Czech Republic. Currently (2015), this phenomenon is relevant only in the OKR 
in the Mining Plant 3 (until 2015 the Paskov Mine) because other locations with underground coal mining in conditions with coal and gas outburst hazard have already been downsized and closed (Hudeček, 2014).

The coal and gas outburst is defined as an abrupt ejection of at least 0.5 ton of coal from the coal seam to the mine workings, connected with a sudden large exhalation of gases. This issue is usually accompanied by these manifestations (Decision ref. no 3895/2002 of District Mining Authority in Ostrava):

(a) The formation of a cavern, whose neck is generally narrower than other parts of the cavern, or the formation of gas paths (channels), which enabled gas escape, in which event the cavity does not have to be visible;

(b) Fine coal dust deposition on the mine workings support and shaft lining.

The occurrence of outbursts depends upon many factors. Considering the outbursts that have been recorded in the Mining Plant 3 , it can be concluded that the most important factors include (Hudeček \& Urban, 2006):

1. The degree of coalification - the coalification process leads to changes of coal matter and also to significant changes in the physico-mechanical properties. This change of properties is connected with the genesis of production of gases bound to coal mass, especially methane. The degree of coalification has a major impact on the properties of coal that affect its sorption properties and the ability to accumulate energy. We can say that with increasing coalification, the amount of methane absorbed in coal is increased (Hudeček, 2014);

2. The distance from the cover - in the Mining Plant 3, superficial deposits mainly consist of calcareous clays. This resulted in complete closure and isolation of carboniferous mountains. For this reason, the largest number of outbursts occurred in the primary stage of opening of the deposits. With increasing distance from the cover formation, the number of outbursts significantly decreases;

3. Tectonic faults - The analysis of outburst occurrence cases showed that in the vast majority of the cases, a tectonic fault or a zone of tectonic faults is present. It follows that at the occurrence of each tectonic fault, safety measures must be increased (Hudeček, 2014).

The severity of rock and gas outbursts depends on the impact of these anomalous geomechanical phenomena on the lives and health of miners, technology, and the mining enterprise economy.

Economic impacts of coal and gas outbursts are becoming increasingly important especially now, when not only Czech but also world mining industry is in deep recession.

Each activity is considered mainly in economic terms. In this case, the additional costs and expenses have to be taken into account, compared to a state where preparatory works and mining are not at risk related to outbursts. The resulting benefits of prevention measures can be assessed at two levels (Hudeček, 2014): (i) Savings resulting from the fact that the outbursts will not occur and there will be no material damage, period of idleness with respect to the driven length and mining, injury or death of workers. It should be emphasized that 
it is not possible to evaluate an employee's injury, let alone death economically; (ii) The second level contains the assessment of revenue and profit arising from the possibility of mining seams with outburst hazard. If preventive measures were not taken, it would be necessary to refrain from mining seams threatened with outbursts, which would result in the corresponding economic impact Dvořáček et al. (2013).

The purpose of the applied methods is to prevent the occurrence of anomalous geomechanical phenomena or minimize the consequences of these phenomena. Therefore, the preventive measures are divided into active and passive ones (Frýdl, 2015), Hudeček et al. (2013).

Active measures are preferred and used to:

a) Remove sources of critical tensions in the mountain massif. Solutions take place at the stage of planning and address the placement of mine workings in time and space (Decision ref. no 3895/2002 of District Mining Authority in Ostrava, Instructions for Mines with a Rock and Gas Outburst hazard of District Mining Authority in Ostrava).

b) Influence the mountain massif properties. These measures are aimed at eliminating or limiting a critical condition. They include degasification of boreholes and irrigation of seams, which are carried out in advance, before mine workings are driven (Decision ref. no 3895/2002 of District Mining Authority in Ostrava, Instructions for Mines with a Rock and Gas Outburst hazard of District Mining Authority in Ostrava).

c) Influence the process, disrupting the mountain massif structural units. The measures are used at the time, when the critical state of stress occurs, and our purpose is to affect the process of disrupting the structural units to prevent the undesirable phenomenon (Decision ref. no 3895/2002 of District Mining Authority in Ostrava, Instructions for Mines with a Rock and Gas Outburst hazard of District Mining Authority in Ostrava).

Active prevention methods include: (i) Using the protective seam; (ii) Relief drilling; (iii) Relief (non-break-off) blasting; (iv) Irrigation.

The applied passive means of prevention are aimed at protecting people and equipment against the consequences of those events that could not be prevented. They also include shock blasting. It is intended to induce an outburst while employees' lives are not threatened, or if active methods cannot be used or their efficacy is not sufficient (Decision ref. no 3895/2002 of District Mining Authority in Ostrava, Instructions for Mines with a Rock and Gas Outburst hazard of District Mining Authority in Ostrava).

The applied passive methods of prevention include: (i) Shock blasting; (ii) Coal mining without the presence of people in the coalface; (iii) Removing people from the workplace.

Application of a specific approach is the result of comprehensive evaluation, which should also include the economic point of view. Moreover, it is the economic point of view that has not been much accepted so far. Therefore, the authors aim to present the economic assessment of the selected measures 
focused on rock and gas outburst prevention in the conditions of the Mining Plant 3 in OKD, a. s.

\section{METHODS AND MATERIAL}

To assess the effectiveness of measures against rocks and gas outbursts, it is necessary to determine the cost of predictive and preventive measures in the process of driving long mine workings and during mining. We elaborated economic evaluation of the above-mentioned preventive methods used in mining in the Mining Plant 3.

These are simulation calculations concerning the costs that arise under given assumptions. Based on the obtained data, we proceeded from the current mining conditions.

The economic assessment of the costs was made for the coalface no. 080211. In this coalface, we calculate the cost for $100 \mathrm{~m}$ of the target length of the extraction process. The length of the coalface is 127 meters.

The economic model itself has been developed based on the generic division of the total costs, which can be generally expressed as follows (Thuesen \& Fabrycky, 1984).

$$
T C=N m+N e+N o s+O
$$

where:

$T C$ - total costs;

$\mathrm{Nm}$ - material costs;

$\mathrm{Ne}$ - energy costs;

Nos - staff costs;

O- depreciation

Specific items vary with respect to the applied way of coal and gas outburst.

\section{Mining Plant 3 - locality of interest}

Mining Plant 3 (the former Paskov Mine) was established in 1960 and mining began 6 years later. The District Mining Authority in Ostrava listed the mine among those with coal and gas outburst hazard. The first outburst occurred on 24 February 1970, and the most recent outburst was registered on 19 December 2012. By then, there had been a total of 147 outbursts (Frýdl, 2015, Hudeček, 2014).

The mine is located about $20 \mathrm{~km}$ south of the city of Ostrava. The mining field area is about $42 \mathrm{~km}^{2}$ and it is divided into three parts: the locality of Staříc I in Sviadnov, the locality of Staříc II in Staříč, and the locality of Staříc III in Chlebovice. Within the mining area, the productive Carboniferous is represented in the lower part of the Ostrava Formation, which consists of Petřkovice and Hrušovská layer. The extracted thickness of the abovementioned layers range between 75 to $200 \mathrm{~cm}$. The seams have small thickness, but they contain high-quality coking hard coal. Late Carboniferous tectonic structure in the mining area is polytype, mainly due to the compression and extensive deformation. This was caused by sliding of the Beskydy nappe on coal-bearing layers. (Hudeček \& Urban, 2006). 
This leads to other consequences, i.e. closing gas in that area. This created a predisposition to high gas emission of coal seams and coal and gas outburst hazard. Currently, it is the only mine in the Czech Republic that includes seams with coal and gas outburst hazard. Driving and mining technology is adapted to it. For driving, the traditional technology involving blasting is used. In mining, coal plows and individual hydraulic supports are most frequently used, and since 2013, one shearer has been deployed in one coalface. Currently, preparatory and mining work are being carried out in the depth ranging from 880 to $1,150 \mathrm{~m}$ below the surface. The annual production of the mine is about 850,000 tons of coking coal.

\section{RESULTS}

The authors focused on three methods of protection against the effects of rock and gas outbursts: the coal seam irrigation, relief boreholes, and relief blasting. The basis of economic assessment and primarily the results themselves are stated in the sub-sections of this chapter.

\section{The coal seam irrigation}

The calculation will be made for ideal conditions. This means that the entire coalface will be effectively influenced by long irrigation boreholes from the main gate and the air gate (Appendix - Figure 1).

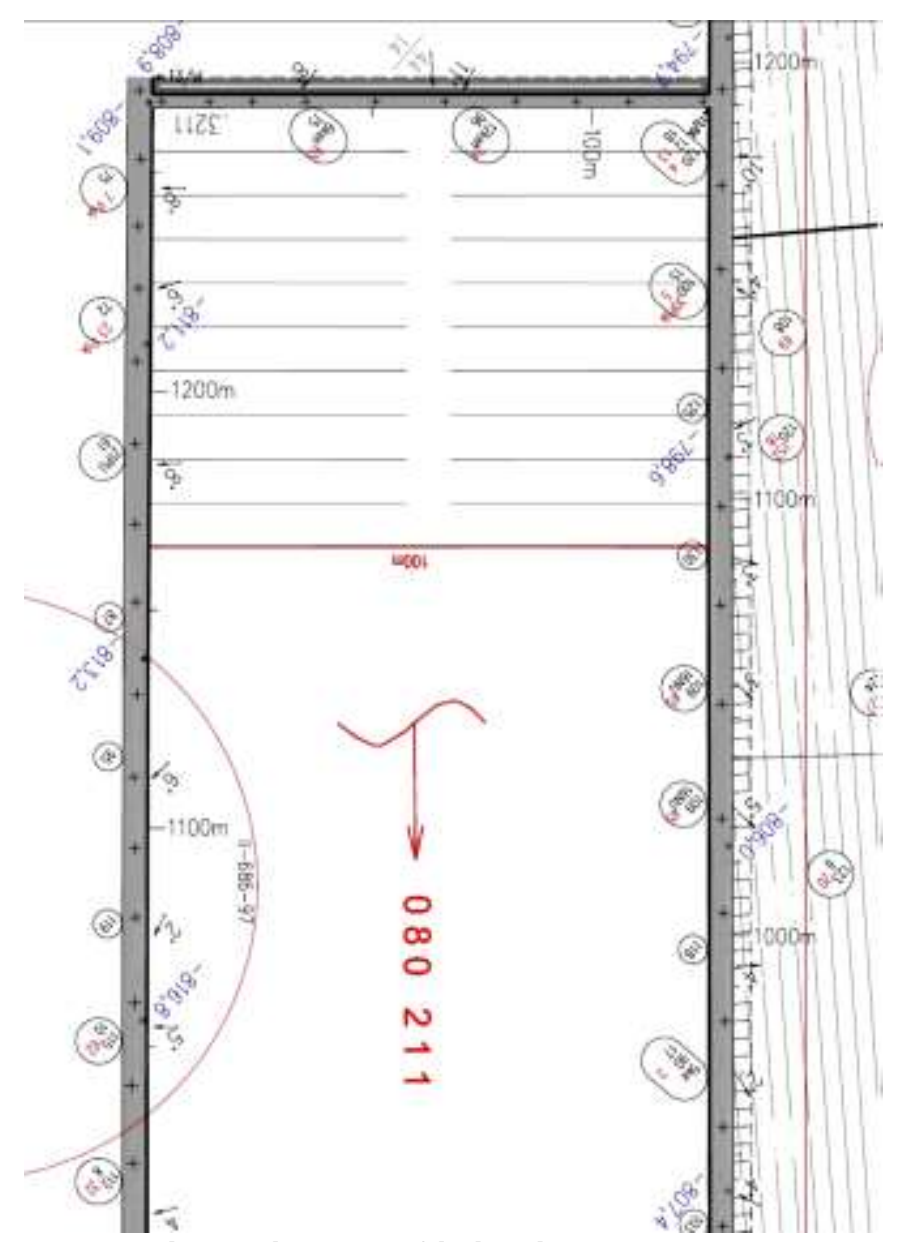

Fig. 1 Diagram of irrigation boreholes 
For the thoroughly affected area of efficient irrigation, it will be necessary to drill and irrigate 20 boreholes. A two-man crew, with an average performance of $10 \mathrm{~m} /$ hour, will conduct drilling. In total, 30 shifts will be needed. The RVS-1 drilling machine will be used and we assume the average drilling time will be 4 hours/shift. The compressed air consumption for the given machine is 250 $\mathrm{m}^{3} /$ hour. Irrigation will take place from pressure distribution of mining water supply. Additional costs will be itemized as follows ${ }^{1}$ (Table 1).

Table 1 Costs of irrigation

\begin{tabular}{|c|c|}
\hline $\begin{array}{l}\text { Material costs (the cost of boring rods, boring } \\
\text { crowns, irrigation pipes, cement seal, and } \\
\text { water) in total: } 562.81 \text { USD }\end{array}$ & $\begin{array}{l}\text { Energy costs (the cost of compressed } \\
\text { air for driving the drilling equipment) } \\
\text { in total: } 560.05 \text { USD }\end{array}$ \\
\hline $\begin{array}{l}\text { Consumption of boring rods: } 1 \text { piece } \\
\text { The price of a boring rod: } 148.21 \text { USD/pc } \\
\text { The cost of boring rods: } 148.21 \text { USD } \\
\text { Consumption of boring crowns: } 4 \text { pcs } \\
\text { The price of a boring crown: } 66.30 \text { USD/pc } \\
\text { The cost of boring crowns: } 265.21 \text { USD } \\
\text { Consumption of irrigation pipes: } 40 \text { pcs } \\
\text { (2 pcs/borehole) } \\
\text { The price of an irrigation pipe: } 2.43 \text { USD/pc } \\
\text { The cost of irrigation pipes: } 97.03 \text { USD } \\
\text { The price of cement seal } 1.33 \text { USD/borehole } \\
\text { The cost of cement seal: } 26.68 \text { USD } \\
\text { Water consumption: } 5.5 \mathrm{~m}^{3} / \mathrm{borehole} \\
\text { The price of water: } 0.10 \text { USD/m } 3 \\
\text { The cost of water (irrigation): } 11.22 \text { USD } \\
\text { Consumption of water (irrigation): } 4.8 \mathrm{~m}^{3} / \mathrm{shift} \\
\times 30=144 \mathrm{~m}^{3}\end{array}$ & $\begin{array}{l}\text { Compressed air consumption: } \\
1,000 \mathrm{~m}^{3} / \mathrm{shift} \\
\text { Compressed air consumption in total: } \\
30,000 \mathrm{~m}^{3} \\
\text { The price of compressed air: } \\
18.67 \mathrm{USD} / 1000 \mathrm{~m}^{3}\end{array}$ \\
\hline $\begin{array}{l}\text { Staff costs (wages of workers with extra pay, } \\
\text { national social and health insurance paid by } \\
\text { the employer) in total: } 4,030.56 \text { USD }\end{array}$ & $\begin{array}{l}\text { Depreciation (the boring machine wear } \\
\text { expressed in USD) } \\
\text { in total ( } 30 \text { shifts) } 22.15 \text { USD }\end{array}$ \\
\hline $\begin{array}{l}\text { Hourly rate: } 6.27 \text { USD/hour } \\
\text { Number of hours per shift: } 8 \text { hours. } \\
\text { Number of shifts: } 30 \\
\text { Number of employees: } 2 \\
\text { Wage costs: } 3,007.88 \text { USD } \\
\text { Social security and health insurance: } 34 \%\end{array}$ & $\begin{array}{l}\text { The acquisition price of a boring machine: } \\
6,458.57 \text { USD } \\
\text { Depreciation: } 8 \text { years } \\
\text { Annual depreciation: } 808.57 \text { USD } \\
\text { Depreciation per shift ( } 356 \text { days a year; } \\
\text { three-shift operation): } 0.74 \text { USD/shift }\end{array}$ \\
\hline \multicolumn{2}{|c|}{ Costs of irrigation from the gates amount to: $5,175.57$ USD } \\
\hline
\end{tabular}

\section{Relief boreholes}

For this method, we chose two options of the calculation method. Option A will be used for a favourable development of prognosis measurements. For this option, we selected the location of boreholes in the middle of the seam thickness with $5 \mathrm{~m}$ spacing (Appendix - Figure 2).

\footnotetext{
${ }^{1}$ Original dates based in CZK (currency Czech crown). The exchange rate from 2020-02-28 is 23.124 CZK/USD.
} 


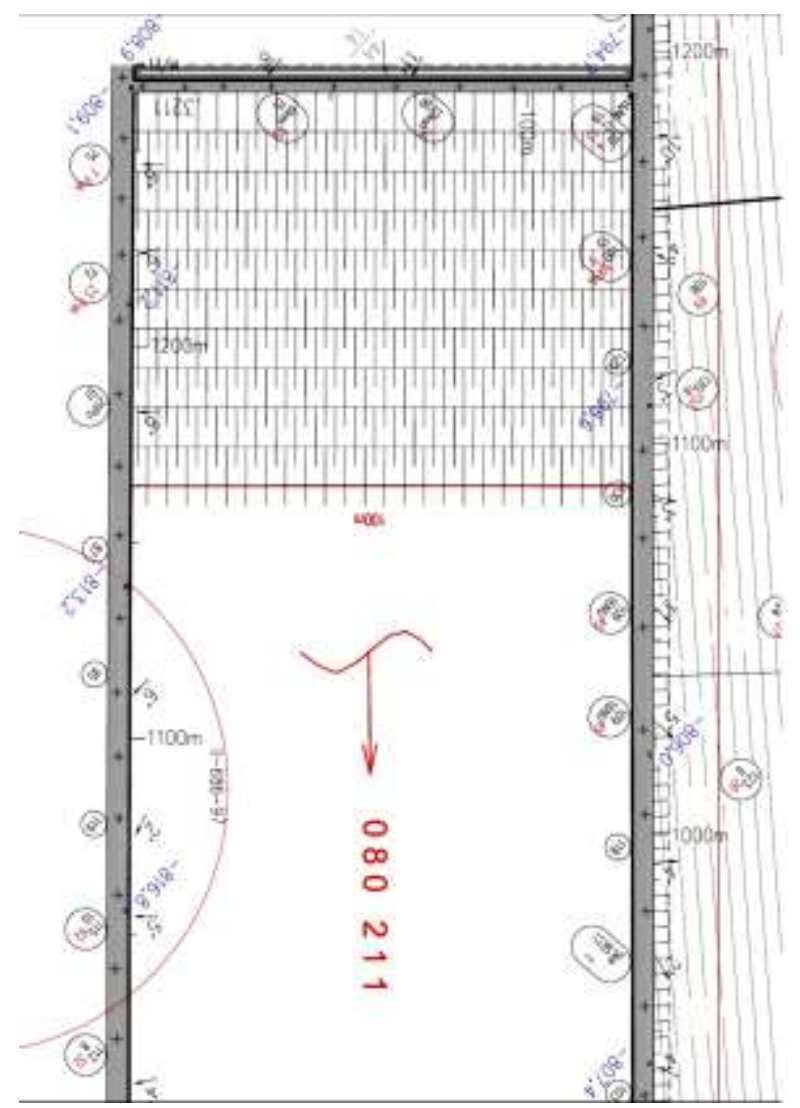

Fig. 2 Diagram of relief boreholes (5 $\mathrm{m}$ spacing)

Option B is used for unfavourable developments of prognosis measurements. In this case, we selected the borehole spacing of 3 meters (Appendix - Fig. 3).

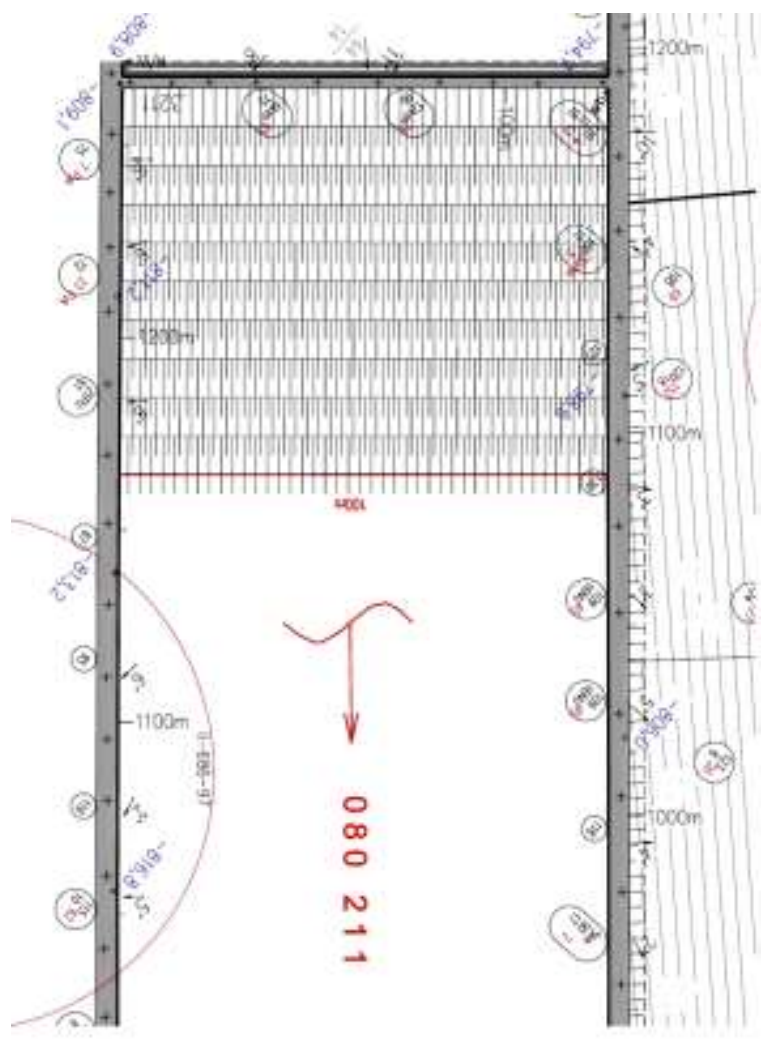

Fig. 3 Diagram of relief boreholes ( $3 \mathrm{~m}$ spacing) 
The boreholes will also be situated in the middle of the seam thickness. The boreholes will be drilled in the distance up to 15 meters and continuous 5-meter advance before the coalface will be maintained.

The Turmag PII boring machine will be used for drilling, together with spiral rods and boring crowns with a diameter of $115 \mathrm{~mm}$. The boring machine operation will be ensured by two workers. On average, they will manage to drill three boreholes per shift and the average net drilling time is $225 \mathrm{~min}$. Other data are taken into account in each case:

\section{Variant A)}

For the selected procedure, it will be necessary to drill a total of 250 boreholes, which we divide into individual cycles of 25 boreholes. During one cycle, $375 \mathrm{~m}$ is drilled. The cost of the relief boreholes (Table 2) will be itemized for 1 cycle (25 boreholes):

Table 2 Cost of relief boreholes

\begin{tabular}{|c|c|}
\hline $\begin{array}{l}\text { Material costs (the cost of drilling rods): } \\
\text { in total: } 318.37 \text { USD }\end{array}$ & $\begin{array}{l}\text { Energy costs (the cost of compressed air } \\
\text { for driving the boring machine) in total: } \\
350.03 \text { USD }\end{array}$ \\
\hline $\begin{array}{l}\text { Consumption of boring rods: } 3 \text { pieces } \\
\text { The price of a boring rod: } 106.12 \text { USD/pc }\end{array}$ & $\begin{array}{l}\text { The time of drilling } 1 \mathrm{~m}: 5 \mathrm{~min} \\
\text { The time of drilling } 1 \text { cycle }(375 \mathrm{~m}) \text { : } \\
1,875 \mathrm{~min} \\
\text { Compressed air consumption: } 10 \mathrm{~m}^{3} / \mathrm{min} \\
\text { The price of compressed air: } 18.67 \\
\text { USD } 1000 \mathrm{~m}^{3}\end{array}$ \\
\hline $\begin{array}{l}\text { Staff costs (wages of workers with extra pay, } \\
\text { national social and health insurance paid by } \\
\text { the employer) in total: } \mathbf{1 , 2 0 9 . 1 7} \text { USD }\end{array}$ & $\begin{array}{l}\text { Depreciation (the boring machine wear } \\
\text { expressed in USD) in total ( } 9 \text { shifts) } \\
\mathbf{2 1 . 6 0} \text { USD }\end{array}$ \\
\hline $\begin{array}{l}\text { Hourly rate: } 6.27 \text { USD/hour } \\
\text { Number of hours per shift: } 8 \text { hours. } \\
\text { Number of shifts per cycle: } 9 \\
\text { Number of employees: } 2 \\
\text { Wage costs: } 902.37 \text { USD } \\
\text { National social and health insurance: } 34 \%\end{array}$ & $\begin{array}{l}\text { The acquisition price of a boring machine: } \\
21,022,84 \text { USD } \\
\text { Depreciation time: } 8 \text { years } \\
\text { Annual depreciation: } 2,627.86 \text { USD } \\
\text { Depreciation per shift ( } 356 \text { days a year; } \\
\text { three-shift operation): } 2.40 \text { USD/shift }\end{array}$ \\
\hline \multicolumn{2}{|c|}{$\begin{array}{l}\text { Costs in total for } 1 \text { cycle of relief boreholes: } 1.877 .57 \text { USD } \\
\text { Costs in total for } 10 \text { cycles of relief boreholes: } 18,775.74 \text { USD }\end{array}$} \\
\hline
\end{tabular}

\section{Variant B)}

In this case, we have to drill 410 boreholes, i.e. 41 boreholes for one cycle, so during one cycle, $615 \mathrm{~m}$ are drilled. The remaining details are the same as for variant $A$, see Table 3 .

Table 3: Cost of relief boreholes

\begin{tabular}{|l|l|}
\hline Material costs in total: $\mathbf{5 3 0 . 6 2}$ USD & Energy costs in total: $\mathbf{5 7 4 . 0 5}$ USD \\
\hline Consumption of boring rods: $5 \mathrm{pC}$ & The time of drilling 1 meter: $5 \mathrm{~min}$ \\
The price of a boring rod: $106.12 \mathrm{USD} / \mathrm{pc}$ & The time of drilling 1 cycle $(615 \mathrm{~m}): 3,075$ \\
& min \\
& Compressed air consumption: $10 \mathrm{~m}^{3} / \mathrm{min}$ \\
& The price of compressed air: \\
& 18.67 USD $/ 1000 \mathrm{~m}^{3}$ \\
\hline Staff costs in total: $\mathbf{1 , 8 8 0 . 9 3}$ USD & Depreciation in total (14 shifts) 33.60 USD \\
\hline Hourly rate: 6.27 USD/hour & The price of a boring rod: $21,022.84$ USD \\
\hline
\end{tabular}




\begin{tabular}{|l|l|}
\hline Number of hours per shift: 8 hours & Depreciation time: 8 years \\
Number of shifts per 1 cycle: 14 & Annual depreciation: $2,627.86$ USD \\
Number of employees: 2 & Depreciation per shift (356 days a year; \\
Wage costs: $1,403.68$ USD & three-shift operation): 2.40 USD/shift \\
National social and health insurance: $34 \%$ & \\
\hline Costs in total for 1 cycle of relief boreholes: $\mathbf{3 , 0 1 9 . 2 0 ~ U S D ~}$ \\
Costs in total for 10 cycles of relief boreholes: $\mathbf{3 0 , 1 9 2 . 0 2}$ USD \\
\hline
\end{tabular}

Source: Own processing

\section{Relief blasting}

The use of this procedure of preventive measures will be selected in case of measuring supercritical values of prognosis measurements even after applying some of the above-mentioned measures. For influencing the coal seam, the spacing of boreholes will be $5 \mathrm{~m}$ and the length of boreholes $5 \mathrm{~m}$ as well (Appendix - Figure 4).

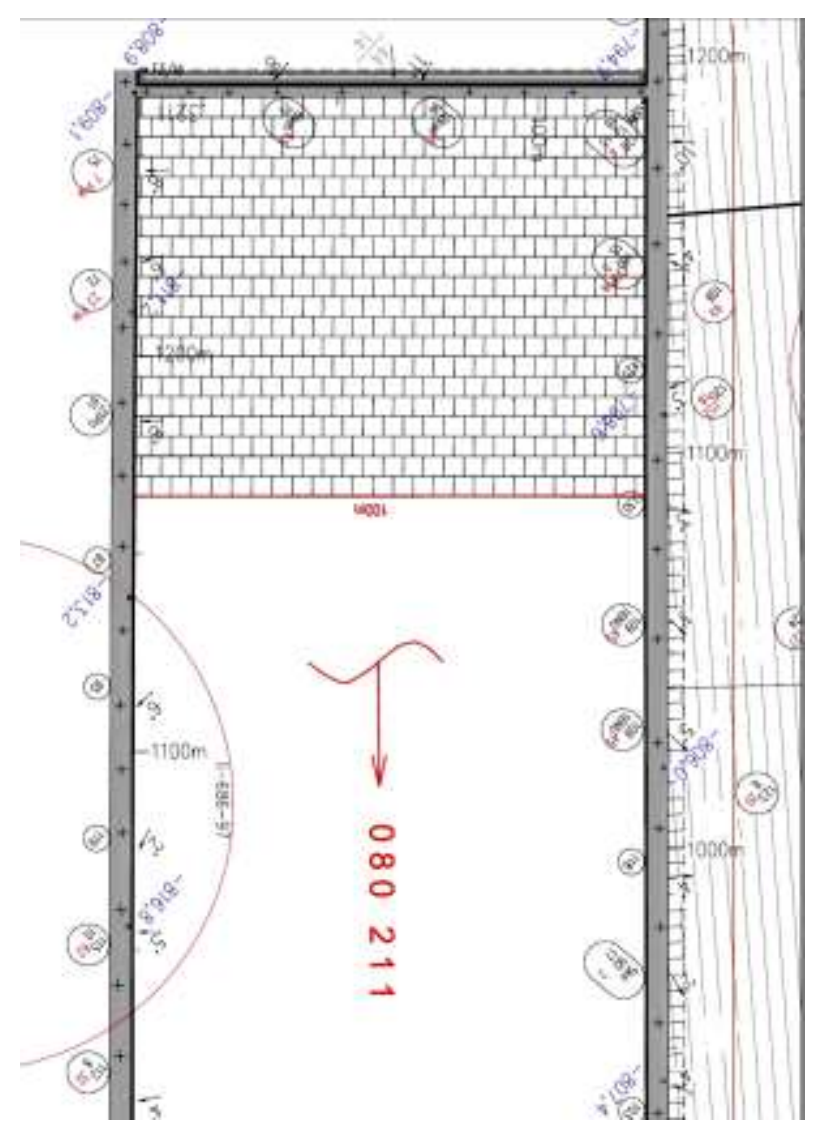

Fig. 4 Diagram of boreholes for relief blasting work

The hand-held pneumatic drill PVN 42 will be used for drilling. For the entire length of the coal face, 6 shifts will be necessary, during which 25 boreholes will be drilled. It will mean one cycle for our calculation. When implementing this non-break-off blasting work, we will use second-category anti-gas explosives safe for mines. The amount of the explosive for one borehole is 1 kilogram. For this blasting work, we will use water seal in the cover. Four pieces of the seal will have to be used for one borehole.

The calculated cost items for the relief blasting work in the coal faces, see Table 4. 
Table 4 Cost of relief blasting

\begin{tabular}{|l|l|}
\hline $\begin{array}{l}\text { Material costs (the cost of explosives, } \\
\text { igniting agents, seal and boring rods - } 1 \\
\text { cycle/25 boreholes) in total: } 321.93 \text { USD }\end{array}$ & $\begin{array}{l}\text { Energy costs (the cost of compressed air } \\
\text { for drilling - } 1 \text { cycle/25 boreholes) in total: } \\
\mathbf{1 1 . 9 5} \text { USD }\end{array}$ \\
\hline The price of explosive: 2.16 USD/kg & Compressed air consumption: $640 \mathrm{~m}^{3}$ \\
Consumption of explosive: $25 \mathrm{~kg}$ & The price of compressed air: 18.67 \\
USe cost of explosive: 52.56 USD & \\
The price of an igniting agent: 1.17 USD/pc & \\
Consumption of igniting agents: 25 pieces & \\
The cost of igniting agents: 29.31 USD & \\
The price of seal: 0.22 USD/pc & \\
Consumption of seals: 100 pieces & \\
The cost of seals: 22.24 USD & \\
The price of a boring rod: $224.29 / p c$ & Depreciation in total: 0.00 USD \\
Consumption of boring rods: 1 piece & \\
The cost of boring rods: 217.83 USD & \\
\hline $\begin{array}{l}\text { Staff costs (wages for workers in the } \\
\text { coalface and the blasting engineer, national }\end{array}$ & \\
social and health insurance paid by the & \\
employer) & \\
in total: 578.58 USD & not considered due to the applied boring \\
\hline Hourly rate of a coalface worker: 7.68 & technology \\
USD/hour & \\
Number of hours per shift: 8 hours & \\
Number of shifts per cycle: 1 & \\
Number of employees: 6 & \\
Staff costs: 368.71 USD & \\
National social and health insurance: $34 \%$ & \\
Staff costs of the coalface workers & \\
in total: 494.07 USD & \\
Hourly rate of the blasting engineer: 7.88 & \\
USD/hour & \\
Number of hours per shift: 8 hours & \\
Number of shifts per cycle: 1 & \\
Number of employees: 1 & \\
Staff costs: 63.07 USD & \\
National social and health insurance: $34 \%$ \\
Staff costs of the blasting engineer \\
in total: 84.51 USD
\end{tabular}

Source: Own processing

\section{The method of using protective seam}

The method using the protective seam applied in the Mining Plant 3 is generally based on mutual storage conditions of the seams and sequences of their extraction. Therefore, economically we can say that the cost of this prevention method for any coalface with potential coal and gas outburst is equal to zero. With this method, there is no consumption of materials, energy or operational shifts, which means that it is the most effective method of prevention (Decision ref. no 3895/2002 of District Mining Authority in Ostrava) (Instructions for Mines with a Rock and Gas Outburst hazard of District Mining Authority in Ostrava). However, if we deliberately choose this type of prevention because of the great interest in the particular coalface (coal quality, high yield from the block, safety at work etc.), and we would have to extract the nearest coal block in the effective distance because of that, the costs of this kind of prevention after deducting the 
price of coal from the under-mining or over-mining coalface would probably be considerably higher. The cost of preventing coal and gas outbursts in the concerned coalface would then analogously increase or decrease according to the profitability extracting the under-mining or over-mining coalface, i.e. the price of coal, shifts, material, etc. In this case, however, it is an unrealistic example.

\section{Comparison of coal and gas outburst prevention methods}

In economic terms, the protective seam appears to be the optimum method because this activity requires no cost. It is clear, however, that the operating conditions do not always allow this method to be applied - Instructions for Mines with a Rock and Gas Outburst Hazard and Decision ref. no. 3895/2002 of District Mining Authority in Ostrava. Therefore, it is necessary to compare the remaining coal and gas prevention methods.

Multiple criteria were applied while comparing the coal and gas prevention methods to enable a multilateral view of the issue. The authors chose the following criteria: cost, consumption of time, labour intensity, efficiency.

The inputs for comparison are shown in Table 5, while the labour intensity and efficiency was expertly determined by the authors.

Table 5 The input data for the comparison of coal and gas outburst prevention methods

\begin{tabular}{|l|c|c|c|c|}
\hline $\begin{array}{c}\text { Coal and gas } \\
\text { outburst } \\
\text { prevention } \\
\text { option }\end{array}$ & Irrigation & $\begin{array}{c}\text { Relief } \\
\text { boreholes - A }\end{array}$ & $\begin{array}{c}\text { Relief } \\
\text { boreholes - B }\end{array}$ & $\begin{array}{c}\text { Relief } \\
\text { blasting } \\
\text { work }\end{array}$ \\
\hline Costs /USD/ & $5,175,57$ & $18,775.74$ & $30,192,02$ & $18,249.22$ \\
\hline Labour intensity & 1 & 2 & 3 & 4 \\
\hline Efficiency & 2 & 2 & 2 & 2 \\
\hline $\begin{array}{l}\text { Consumption } \\
\text { of time/days/ }\end{array}$ & 30 & 90 & 140 & 20 \\
\hline
\end{tabular}

Note Rating: 1 - the best, 5 - the worst

Source: Own processing

The actual comparison was made by applying the principles of the decision analysis. The results of the comparison are shown in Table 6 and Figure 5.

Table 6 Simple usability of coal and gas outburst prevention methods

\begin{tabular}{|l|c|c|c|c|}
\hline $\begin{array}{c}\text { Coal and gas } \\
\text { outburst } \\
\text { prevention } \\
\text { option }\end{array}$ & Irrigation & $\begin{array}{c}\text { Relief } \\
\text { boreholes - A }\end{array}$ & $\begin{array}{c}\text { Relief } \\
\text { boreholes - B }\end{array}$ & $\begin{array}{c}\text { Relief } \\
\text { blasting } \\
\text { work }\end{array}$ \\
\hline Costs /USD/ & 100 & 28 & 17 & 29 \\
\hline Labour intensity & 100 & 50 & 33 & 25 \\
\hline Efficiency & 100 & 100 & 100 & 100 \\
\hline $\begin{array}{l}\text { Consumption } \\
\text { of time /days/ }\end{array}$ & 68 & 22 & 14 & 100 \\
\hline Simple usability & 368 & 200 & 164 & 254 \\
\hline
\end{tabular}

Source: Own processing 


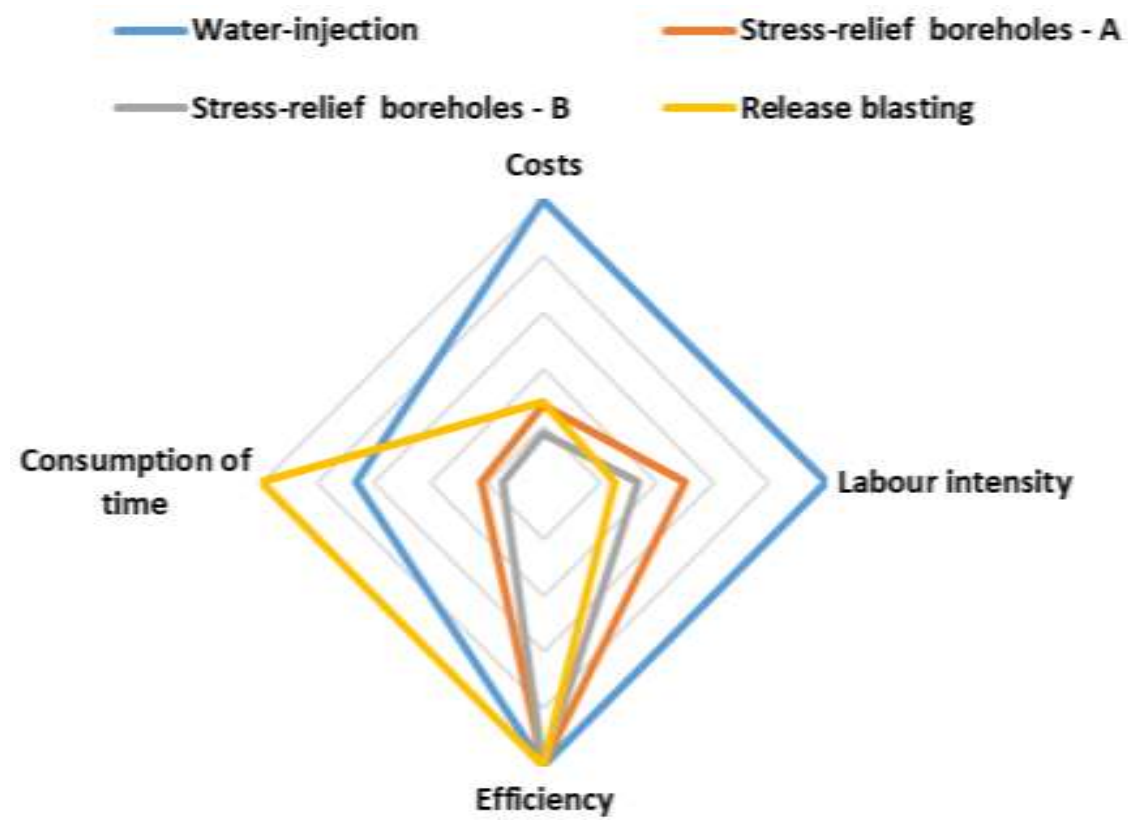

Fig. 5 Radar chart of the usability of coal and gas outburst prevention methods Source: Own processing

Table 6 and Figure 5 clearly show that the method of irrigation has the highest efficiency.

\section{DISCUSSION}

The considered methods offer the same efficiency of coal and gas prevention, which is confirmed by empirical findings of the OKD mining enterprise. Leaving aside the economic aspect, irrigation of the coal seam appears to be a favourable method in terms of efficiency. Additionally, it is the only one of the above-mentioned measures that can be applied in advance and does not limit the planned mining.

In terms of time, relief blasting needs the least amount of time. The cost of this method is the lowest compared to the remaining methods.

Relief boreholes with spacing of $3 \mathrm{~m}$ (option B) show the worst results, but not in terms of efficiency. Taking into account only the economic aspect, the costs exceed the cost of the coal seam irrigation almost 6 times.

It is therefore clear that relief blasting work and relief holes can be recommended only in the event that after application of the seam irrigation supercritical values are measured. Moreover, a disadvantage of this method is the fact that boreholes are drilled from the area of the coalface and they interrupt the production cycle of mining. These methods also increase the risk of personal injury.

A separate issue is the use of the protective seam that could be described as a method with zero costs, but it could not be used for the particular coalface because of unsuitable geological deposition and the interim order of the closest seams that are being extracted in the roof or the floor of the seam. 
To ensure the complete assessment of the methods, we should also discuss the situation when, despite the deployment of coal and gas outburst prevention methods, an emergency occurs.

Therefore, now we will calculate the situation when outburst prevention has not been realized and a coal and gas outburst occurred in the coalface 080211. The individual hydraulic support was used in the coalface. In case of a coal and gas outburst in the coalface, the following costs and losses can be expected:

- Costs of intervention by rescuers during the elimination: the wage is derived from the length of intervention and the hourly rate of intervention;

- Losses from the period of idleness in mining: the operating profit loss can be derived from the idleness in mining;

- Material costs: damage or destruction of the individual hydraulic supports. When eliminating the consequences of an outburst, the intervention of rescuers in the initial phase can be expected to take about 8 hours, i.e. approx. 2,021.43 USD.

The above-mentioned incident results at least one-day idleness in mining in the coalface (it is also connected with the time and events during the investigation by the expert committee). With the planned mining in the coalface 080211 of 300 t/day on average and the current coal prices, this means a loss of approximately 40,428.54 USD.

Even outbursts of small to moderate intensity often result in losses of the individual hydraulic supports. Hydraulic props, roof bars and jointing shoes cannot always be safely removed out of the blow. With approximate depreciation of about 10 pieces of the individual hydraulic supports, depreciation in the amount of about 4,042.85 USD can be expected.

Therefore, in case of an outburst of a small intensity, an immediate financial loss of around 0,040 - 0,060 million USD can be anticipated. Other costs of the renewal of the coalface operation subsequently result from prescribing and applying stricter preventive and safety measures, which always follow after similar events. The total amount can easily exceed 0,081 million USD and more.

\section{CONCLUSIONS}

In this contribution, we have attempted to quantify the cost of preventive measures in a part of the coalface 080211 . We proceeded from the actual values used in the Mining Plant 3, some of the data had to be calculated from the published resources of the mining company, some of them were a simulation.

The above-mentioned simulation calculation have shown that the total costs of the preventive measures in the coalfaces in the Mining Plant 3 amount to millions CZK per year (current exchange rate equals to $24.735 \mathrm{CZK/USD)}$. However, it is necessary to point out that, among other things, these measures have prevented outbursts in recent years. Considering this fact, we can regard costs incurred as effectively used.

Outburst prevention measures are now part of the measures to ensure the safety and protection of people and property of the mining company. Cost 
savings related to outburst prevention measures could be negatively overbalanced by costs and losses associated with the emergence of a series of outbursts, which could even result in the abandonment of certain parts of the mining field, causing loss of coal reserves.

\section{REFERENCES}

Budeba, M. D., Joubert, J.W. and Webber-Youngman R.C.W. Modelling and determining the technical efficiency of a surface coal mine supply chain. Journal of the Southern African Institute of Mining and Metallurgy, 2014, vol 114, no. 12, pp. 1001-1008.

Dvořáček, J., Hudeček, V., And Štěrba, J. 2013. Economic Assessment of Safety Measures against Coal and Gas Outbursts. Journal of Mines, Metals and Fuels, INSIO Scientific Books and Periodicals, vol. 61, no. 9-10, pp. 291-294.

Franczek, R. Rozpoznanie i zwalczanie zagrozenia wyrzutami gazow i skal w kopalniach wegla kamiennego. 1st edn. Gliwice, Politechnika Śląska w Gliwicach, 2006.

Frýdl, L. Posouzení jednotlivých způsobů prevence průtrží uhlí a plynů při dobývání porubů na závodě Důl Paskov. Bakalářská práce VŠB-TU Ostrava, 2015, pp. 41 (Assessment of the Individual Ways of Preventing Coal and Gas Outbursts during Mining in the Coalfaces in Paskov Mine plant. Bachelor thesis at VŠB-Technical University of Ostrava, 2015, pp. 41).

Hanes, J. Outburst Scoping Study. ACARP 10012, [online]. [cit. 2012-11-30]. Available from: http: //freedownload.is/doc/outburst-online, 2004.

Hudeček, V. Protection of employees against the consequences of rock and gas outbursts in the Czech Republic. 1st edn. Košice, TU Košice, 2014.

Hudecek, V. and Urban, P. Foreign experience, findings and trends in the problems of rock and gas outbursts). Partial report of Czech Science Foundation, No. 105/05/0013, VŠB-TU Ostrava, 2006, 95 pp. ISBN 80-248-1206-1.

Hudeček, V., Urban, P. and Stavinoha, J. Problems of higher gas emission and coal and gas outbursts in the Czech Republic and other countries of the world. Journal of Mines, Metals and Fuels, 2010, vol. 58, no. 8. pp. 212-216+236.

Hudeček, V., Zapletal, P., Stoniš, M. and Sojka, R. Results from dealing with rock and gas outburst prevention in the Czech Republic. Archives of mining sciences, Polish Academy of Sciences, 2013, vol. 58, no. 3, pp. 779-787.

Lát, J., Hudeček, V., Urban, P. and Michalčík, P. The Estimation of a Possibility of Outburst Origin in Long Mine Workings. Journal Acta Montanistica Slovaca, 2007, vol.12, no. 2, pp. 62-72.

Obvodní Báňský Úřad. Instrukce pro doly s nebezpečím průtrží hornin a plynů. Ostrava, 2002 (The District Mining Authority. Instructions for Mines with a Rock and Gas Outburst Hazard).

Rozhodnutí č.j. 3895/2002 Obvodního báňského úřadu v Ostravě (Decision ref. no. 3895/2002 of District Mining Authority in Ostrava).

singh, A. K. Coal exploration - Expanded requirement in India. Journal of Mines, Metals and Fuels, 2009, vol. 57, no 2.

Singh, R.V.K., Tripathi, D.D., Singh, V.K. Evaluation of suitable technology for prevention and control of spontaneous heating/fire in coal mines, Archives of Mining Sciences, 2008, vol. 53, issue 4, pp. 555-564.

Thuesen, G. J., and Fabrycky, W. J. Engineering economy. $6^{\text {th }}$ edn. New Jersey, Prentice-Hall, Inc, 1984.

Zhang, J.F., Yang, F., Wang, R., Zheng, C., Sun, N., Lei, W., Xu, T., Zhang, J.J., Miao, Z. Study on optimum design of outburst prevention measures in Weijiadi coal mine. PRC: Xian, 4th International Conference on Environmental Science and Material Application (ESMA), December, 15-16, 2018, vol. 252, UNSP 052098, DOI 10.1088/1755-1315/252/5/052098, 2019. 
Zhang, S.C., Li, Y., Shen, B., Sun, X., Gao, L. Effective evaluation of pressure relief drilling for reducing rock bursts and its application in underground coal mines. International Journal of Rock Mechanics and Mining Sciences, vol. 114, pp. 7-16, DOI 10.1016/j.jirmms.2018.12.010, February, 2019.

\begin{abstract}
.
In this paper, the authors focused on the assessment of the individual methods to prevent coal and gas outbursts. The first part deals with a characteristic of this anomalous phenomenon and some basic methods of coal and gas outburst prevention. The second part presents the economic assessment of the costs necessary to ensure the possible prevention methods in the coalface 080211 in the locality of the Paskov Mine, Mining Plant 3, OKD as, Czech Republic. In this coalface, a simulation method was used for calculating costs for the drift length of $100 \mathrm{~m}$ for the use of various prevention methods (irrigation, relief boreholes, relief blasting). The results show the cost of preventive measures during mining intended to eliminate and protect against the formation of coal and gas outbursts. The measures are compared applying the principle of the decision analysis. Four criteria are used for the mutual comparison of the methods (costs, effort, efficiency, time consumption). The comparison has shown that the optimal method to prevent coal and gas outbursts is irrigation.
\end{abstract}

Keywords: coal and gas outbursts, prevention methods, coal seam irrigation, relief boreholes, relief blasting, protective seam 